now it is a common experience that most cases of $\mathrm{CDH}$ can be diagnosed at birth ${ }^{12-15}$ and that proper treatment will lead to the development of completely normal hips. ${ }^{5}$

Rigshospitalet,

Nis Fredensborg

Copenhagen

${ }^{1}$ Fredensborg, N, and Nilsson, B E, Clinical Orthopaedics and Related Research, 1976, 119, 89. Fellander, M, et al, Acta Orthopaedica Scandinavica, 1970, 130, suppl p 36 .

Mears, D C, Lancet, 1974, 2, 780

Gore, D R, Fournal of Bone and foint Surgery, 1974, $56 A, 493$.

Fredensborg, N, fournal of Bone and foint Surgery, 1976, 58B, 272.

Wynne-Davies, R, fournal of Bone and foint Surgery,

Harris, N H, et al, fournal of Bone and foint Surgery, Putti, V, Fournal of Bone and foint Surgery, 1933, 15, 16.

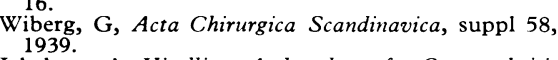

"Jakobsen, A, Vitallium Arthroplasty for Osteoarthritis of the Hip foint. Oslo, Oslo University Press New York, Macmillan, 1957

${ }^{11}$ Lloyd-Roberts, G C, Fournal of Bone and foint Surgery, 1955, 37B,

Marlow, T G, Proceedings of the Royal Society of Finlay, H V L, et al, British Medical fournal, 1967 4, 377 .

4, 377.
${ }^{14}$ Mitchell, G P, fournal of Bone and foint Surgery, 1972,

$\mathbf{5 4 B}, 4$.
Artz, T D, et al, Clinical Orthopaedics and Related Research, 1975, 110, 112

\section{Management of intractable hiccup}

SIR,-I hesitate to add to the list of drugs and other treatments of hiccups compiled by Dr B W A Williamson and Mr I M C Macintyre (20 August, p 501), but they mention methylamphetamine only to record failure in the one case they describe. I have used it to treat hiccups scores of times during the past 25 years and have rarely seen it fail to relieve the symptom. I inject the drug very slowly intravenously until the hiccups stop, usually after 6-12 $\mathrm{mg}$ has been given.

Unfortunately, as a consequence of restrictions introduced because of social abuse, it has become increasingly difficult to obtain the drug in this hospital, especially after normal working hours, so I now use chlorpromazine $25 \mathrm{mg}$ intravenously. However, most hiccups that I see occur during or shortly after recovery from general anaesthesia for upper abdominal operations, when it can be a nuisance to the surgeon or distressing for the patient. Chlorpromazine may not be desirable at these times, but I have found that pentazocine $30 \mathrm{mg}$ intravenously stops these hiccups quickly and effectively. It stops the more prolonged hiccups that occur in uraemia and the diaphragmatic irritation of pneumonia and subdiaphragmatic infection or haemorrhage, but its short action (1-3h) makes it less practical in these situations than chlorpromazine.

\section{E N S FRY}

Department of Anaesthesia,

North Tees General Hospital,
Stockton-on-Tees, Cleveland

\section{Microangiopathy and diabetic gangrene}

SIR,-In your leading article (18 June, p 1555) you assert that microvascular changes in the legs of diabetics predispose directly to gangrene. There is no functional test for the presence of microangiopathy in the leg and the histological evidence is conflicting. Nielsen ${ }^{1}$ concluded that microangiopathy was not a cause of pedal gangrene. Du Plessis ${ }^{2}$ reported that half his patients with foot lesions had histological changes and Moore and Frew $^{3}$ claimed an association between vascular changes and the presence of foot lesions, although this was true only if the most severe cases of microangiopathy were considered. My own studies have demonstrated capillary and arteriolar changes in half the diabetics studied but not more commonly in patients with ulceration or gangrene of the foot.

I believe that the evidence presently available is not sufficiently strong to justify your statement. Further, labelling a patient as suffering from "small-vessel disease" diverts attention from potentially remediable largevessel disease.

IRWIN FARIS

Department of Surgery,

Adelaide, South Australia Nielsen, P E, Scandinavian fournal of Clinical and
Laboratory Investigation, 1973, 31, suppl 128, p 229. Du Plessis, D J, South African fournal of Surgery, 1970, 8, 29.

Moore, J M, and Frew, D O, British Medical fournal,
1965, 2, 19 .

\section{Gastrointestinal symptoms of digoxin toxicity}

SIR,-The article by Dr A Smith and Professor M D Rawlins (30 July, p 309) draws attention to the symptoms of nausea, vomiting, and anorexia as indications of digoxin toxicity and states that the digoxin dosage should be reduced if any of these symptoms occur. We would like to report our experience of assessing these symptoms with respect to the plasma digoxin concentration (PDC)

This laboratory offers a service for the measurement of digoxin in plasma and clinicians are asked to complete a specially designed request card when forwarding a blood sample for analysis. The request card includes a simple tick sheet for common signs or symptoms of cardiac drug toxicity, including gastrointestinal symptoms, together with a three-point assessment of their severity (minor, moderate, or severe).

Details of gastrointestinal symptoms and the PDC have been collated for 412 consecutive requests and are summarised in the accompanying table; symptomatic patients are those reported as having one or more of the symptoms nausea, vomiting, or anorexia at the time the analysis was requested.

The mean PDC of the symptomatic patients was significantly higher than that of the asymptomatic group $(P<0.01)$ and there was an association between the symptoms and increasing PDC ( $\left.\chi^{2} 25.23 ; \mathrm{P}<0.05\right)$. However, there was a wide spread of results among patients complaining of the symptoms and $24 \%$ of these patients had a PDC of 1.3 $\mathrm{nmol} / 1(1 \mathrm{ng} / \mathrm{ml})$ or less. Furthermore, there was no significant difference between the mean PDC of those patients with minor symptoms and that of those displaying moderate or severe symptoms ( $P>0 \cdot 15)$. These results are almost identical with our previous analysis of almost 2000 observations, based on a less detailed assay request card, in which an association between PDC and electrocardiographic signs of toxicity was shown. ${ }^{1}$

Since the symptoms can be caused by congestive heart failure ${ }^{2}$ they are often difficult to evaluate in patients who have been receiving digoxin for some time and could themselves be relieved by an increase in digoxin therapy. Indeed, our results suggest that these symptoms are encountered frequently in patients with low plasma concentrations of the drug and as a diagnostic aid they might be misleading.

In our experience the most prudent course of action when faced with a patient complaining of these symptoms is to determine the PDC, omitting digoxin therapy pending the result. Together with the evaluation of a carefully documented history and other clinical measurements we have found the PDC useful in assessing the probability of the symptoms being an indication of digoxin toxicity.

David W HoLT GLyN N Volans

Poisons Unit New Cross Hospital

${ }^{1}$ Holt, D W, PhD Thesis, University of London, 1976. Chung, E K, Digitalis Intoxication. Amsterdam,

\section{The sleepless child}

SIR,-Dr H Jackson (20 August, p 509) attributes much childhood insomnia to "toddler negative behaviour" by which the child exerts his individuality and then goes on to enumerate treatment in the form of constructive play, hospital admission, or drugs, none of which seem appropriate to his putative cause.

Night crying must be a common complaint. Certainly I have dealt with many cases as a general practitioner as well as one as father of 10-month daughter and another as uncle of 20-month niece. My own hypothesis is that regular night crying is a Pavlovian conditioned reflex. The child wakes and cries (perhaps initially because of an ailment); the mother comes to him with loving attention and a drink; the child repeats his crying nightly and each time is quickly rewarded. With such regular reinforcement the reflex is soon established. It follows that the logical treatment is simply a matter of deconditioning.

It is explained to the mother how she has unwittingly trained her child to cry and that he must now be taught that crying is fruitless. On the appointed night the neighbours are warned that there will be an unusually protracted din but that this is entirely the fault of the doctor. The child cries. Father stamps in, flings down the side of the cot, slaps him once but firmly, flings up the cot side, and

Plasma digoxin concentration and incidence of gastrointestinal symptoms in 412 patients

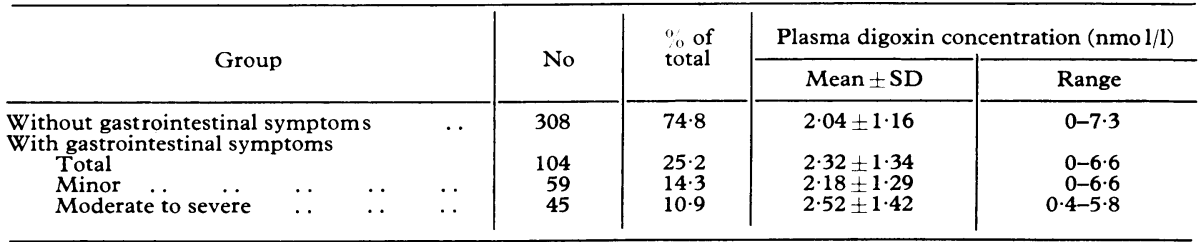

Conversion: SI to traditional units-Digoxin: $1 \mathrm{nmol} / 1 \approx 0.78 \mathrm{ng} / \mathrm{ml}$. 